\title{
Determination of Spiritual Motivation, Leadership and Communication Style of Employee Work Achievement with Organizational Culture as Intervening Variables of the Tanjungpinang City Youth and Sports Agency
}

\author{
Berima Chablullah Wibisono Bambang Satriawan Sri Yanti \\ Faculty of Economics, Batam University, Riau Islands, Indonesia
}

\begin{abstract}
This study aims to determine the effect of Spiritual Motivation, Leadership and Communication Style on Work Achievement and Organizational Culture as an intervening variable. Hypothesis proposed Motivational Motivation determines Organizational Culture, Leadership Determines Organizational Culture, Communication Style Determines Organizational Culture, Spiritual Motivation Determines Work Achievement, Leadership Determines Organizational Culture, Communication Style Determines Determination of Organizational Culture, Determination of Motivation on work performance, communication style determines work performance and organizational culture determines work performance. The sample in this study were all employees at the Tanjungpinang City Youth and Sports Department. The number of samples used were 125 respondents. The data in this study were obtained by distributing questionnaires filled out by respondents. The data obtained were analyzed using data analysis techniques with rock software AMOS 24.0. The value of square multiple correlation Spiritual Motivation, Leadership, Communication Style, and Culture of Organization, showed a figure of $85.1 \%$. Thus, it can be stated that the change in Job Achievements is determined by the contribution of Spiritual Motivation, Leadership, Communication Style, and Culture of Organization, by $85.1 \%$, the remaining $14.9 \%$ is the contribution of other variables that have not been included in this study. Job Changes in Achievements are determined by the contribution of Spiritual correlation Motivation, Leadership, Communication Style, and Culture of Organization which are significantly positive and not significant, but the contribution of each in the square multiple correlation remains above $50 \%$, this shows the model of this study pretty good.
\end{abstract}

Keywords: Spiritual Motivation, Leadership, Communication Style, and Culture of Organization, Job Achievements

DOI: $10.7176 / \mathrm{EJBM} / 12-21-01$

Publication date:July $31^{\text {st }} 2020$

\section{Introduction}

Getting quality public services is a right for every citizen. This is in accordance with the Minister of Home Affairs regulation on Regency / City government article 1 paragraph (2), namely "basic services to the community are the function of the government at the level of people's welfare". The delivery of public services is not only related to adequate facilities and infrastructures. But more important is the element of human resources that exist in these organizations. Increasing the need for public services must be accompanied by the ability of the region to carry out its functions and responsibilities. The most decisive main element in increasing the capacity of the region's ability to carry out public services is the capacity of the local government's human resources.

It is time that the management of the local government bureaucracy in Indonesia prioritizes the element of professionalism rather than mere bureaucracy. The current management of government agencies must refer to the needs of customers (the community) and all stakeholders. According to (Mangkunegara 2016)Human Resources in the company need to be managed properly and professionally in order to create a balance between the needs of employees with the demands and organizational capabilities of the company. In this case, the regional government is demanded to be able to manage its Human Resources properly in order to improve services to the community. To create professional human resources is not easy to do because there are many factors that influence because good performance is a key driver of morale, discipline, and employee achievement in supporting the realization of the goals of an organization or company (Hasibuan 2013).

Theoretically, as described above, the work performance of an employee can be influenced by several factors or variables, such as spiritual motivation, leadership and communication style. Based on the above problems, research needs to be done whether the factors of spiritual motivation, leadership and communication style can also affect employee performance. The results of the study are expected to identify the deficiencies of the Department of Youth and Sports where researchers take research samples to provide the best solution related to the problems that have been previously expressed. This research will analyze the effect of spiritual motivation, leadership and communication style on work achievement in improving employee performance. Where this research will be conducted at the Youth and Sports Department of Tanjungpinang City. 


\subsection{Formulation of the problem}

The following problem formulations in this study are as follows:

1. Does the spiritual motivation directly determine the work performance of Tanjungpinang City Dispora employees?

2. Does the leadership directly determine the work performance of Tanjungpinang City Dispora employees?

3. Does the Communication Style directly determine the work performance of Tanjungpinang City Dispora employees?

4. Does the Organizational Culture determine directly the Work Achievement of Tanjungpinang City Dispora employees

5. Does the Spiritual Motivation directly determine the organizational culture of Tanjungpinang City Dispora employees?

6. Does the leadership directly determine the organizational culture of Tanjungpinang City Dispora employees?

7. Does the Communication Style directly determine the Organizational Culture of Tanjungpinang City Dispora Employees?

\section{Theoretical Basis}

\subsection{Spiritual Motivation Theory}

Something motives and motivation are closely related to the appreciation of a need. The word motive is interpreted as an effort to encourage someone to do something. Starting from the approach the word motive can be drawn in the equation that both express a will behind the action. According to (Hasibuan 2012) the word motivation comes from the Latin movere which means encouragement or move. Meanwhile, if it is associated with human resource management, then this motivation questions about how to be able to direct the power and potential of subordinates to want to work productively so that they reach the set standards and achieve predetermined goals. According to (Tamami 2011) the word spirit comes from the word Latin noun "Spiritus" which means breath and the verb "Spirare" which means to breathe. Seeing the origin of the word, to live is to breathe, and to have a breath means to have a spirit. Being spiritual means having more ties to things that are spiritual or psychological than physical or material things. Spirituality is awakening or enlightenment in achieving the meaning of life and the purpose of life. Spiritual is an essential part of one's overall health and well-being. According to (Abdullah and Majid 2003) spiritual motivation is motivation that is related to the fulfillment of religious needs, which is done by worship as a form of obedience to God. Religiosity can be defined as needs. (Abdullah and Majid 2003) who categorized spiritual motivation into 2 (two) dimensions, namely self-actualization and religion. The characteristics of the religious dimension are based on the concepts of aqeedah, worship and mu'amalah by giving priority emphasis to motivating Islamic consumption behavior.

\subsection{Leadership Theory}

According to (Hasibuan 2013) a leader is someone with leadership authority directing his subordinates to do part of their work in achieving goals. So that leadership is someone who has the nature to be able to use his authority to be able to direct his subordinates to do some of his work in achieving organizational goals. According to (Rivai and Mulyadi 2012), leadership is basically involving others, involving uneven distribution of power between leaders and group members, mobilizing abilities by using various forms of power to influence the behavior of subordinates, and concerning values. General empathy that has an influence on the success of organizational leadership, namely: (1) intelligence, (2) maturity, (3) self-motivation and encouragement of achievement, and (4) attitude of human relations. Meanwhile according to (Bangun 2012) states leadership as a psychological process in receiving responsibility of the task, self, and the fate of others, from several definitions leadership, it can be concluded that leadership is an ability to influence enthusiasm, enthusiasm, security, quality of work and organizational achievements, and the ability to give a role in encouraging individuals and groups to achieve organizational goals.

\subsection{Communication Theory Style}

According to (Zainal n.d.) have defined communication as sending and receiving messages or news between two or more people so that the message can be understood. (Sule and Priansa 2018) stated that in general the style is an attitude, movement, behavior, and gestures that are summarized in the human personality, in this case a leader in an organization. Communication style is defined by (Ruliana 2014) as a set of specialized personal introductory behaviors that are used in certain situations. Each communication style consists of a set of communication behaviors that are used to obtain certain responses or responses in certain situations as well. The suitability of one communication style used, depends on the intent of the sender (sender) and the expectations of the receiver (receiver). Communication Style According to the big Indonesian dictionary, style is a force capable of moving something; strength, ability; attitudes, movements, gestures, actions that mark a person's character, certain movements that are arranged to attract the attention of others. So conclusions can be drawn with communication 
in this study is the process of interaction between leaders and employees in terms of delivery of orders, information, suggestions and objectives of the company that are oral or written that aims to avoid mistakes in work and create a good work environment between leaders and employees for improve employee performance in achieving organizational goals.

\subsection{Organizational Culture Theory}

Culture (culture) comes from the Latin colere which means to process, work, fertilize, and develop, especially processing or farming. Culture is the values and habits that are accepted as a common reference to be followed or respected. While the word organization comes from the Greek organon which means a tool or instrument, in other words the organization is a human aid in other words the organization is a container or tool to gather strength from individuals who have a common goal and shared goals where they are trying to realize the goals This is through joint efforts. (Rivai and Mulyadi 2012) suggest that organizational culture is what employees feel and how this perception creates a model of trust, values, and expectations. Culture as "a pattern of basic acceptance when found, or developed by a particular group as a learning effort to overcome the problems of external adaptation and internal integration that has worked smoothly enough to be considered legitimate and therefore, to teach new members as the correct way to feel, think, and feel the connection with the problem. Meanwhile, according to (Robbins and Judge 2008), organizational culture is a shared perception adopted by members of the organization. (Tampubolon 2008) states that organizational culture is a pattern of basic assumptions to act, determine or develop organizational members in overcoming problems by adapting it from outside and integrating it into the organization so employees can work carefully, and also benefit new employees as a basis for correction of their perceptions, thoughts, and feelings in relationships overcome problems. Some of the above understanding can be concluded that organizational culture is a system of mutual agreement of values, norms and behaviors that apply in an organization that is the basis of behavior for all employees, the nature of increasing and differentiating between one organization with its organization.

\subsection{Theory of Work Achievement}

For organizations, the results of employee performance appraisal are very important and their role in making decisions about various things, such as identifying the needs of education and training programs, recruitment, selection, placement recognition programs, promotions, reward systems and various other aspects of the overall process of human resource management effective. According to (Sutrisno 2013) Job performance is the result of the implementation of a job, both physical / material and non-physical / non-material in carrying out their duties based on the job description, the results need to be assessed after a certain grace period. (Siswanto 2012) referred to work performance is the performance achieved by a workforce by a worker in carrying out the tasks and jobs given to him. In general, the work of a workforce is influenced by, among others, the skills, skills, experience, and sincerity of the workforce concerned.

\subsection{Theoretical Framework}

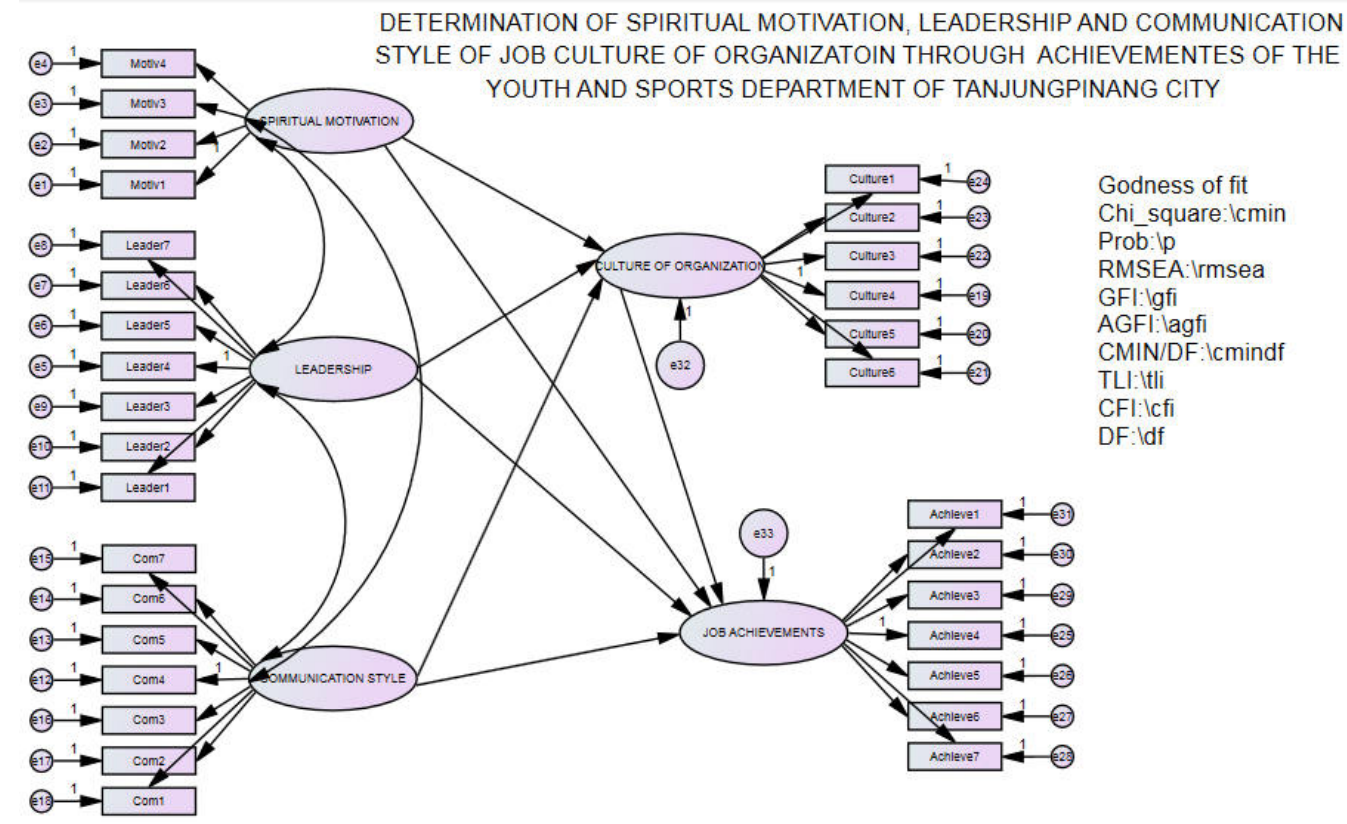




\subsection{Research Hypothesis}

Tentative statements (provisional) which are allegations or guesses about what researchers observe in an effort to understand them. A hypothesis must show a clear structure so that it is easy to know the type of variable and the direction of the relationship between variables, whether positive or negative, a temporary answer to the research problem, is as follows:

1. Spiritual motivation directly determines the work performance of Tanjungpinang City Dispora employees

2. Leadership determines directly the work performance of Tanjungpinang City Dispora employees

3. Communication Style determines directly the work performance of Tanjungpinang City Dispora employees

4. Organizational Culture directly determines the work performance of Tanjungpinang City Dispora employees

5. Spiritual motivation directly determines the organizational culture of Tanjungpinang City Dispora employees

6. Leadership determines directly the organizational culture of Tanjungpinang City Dispora employees

7. Communication style determines directly with the organizational culture of the Tanjung Pinang City Dispora Employees

\section{Research Method}

The location of the study was conducted at the Tanjungpinang City Youth and Sports Agency

\subsection{Population}

Population is a generalization of all subjects and objects of existing research. then the authors determine that the population in this study is the Employees of the Youth and Sports Office of Tanjungpinang City with 125 employees.

\subsection{Sample}

Withdrawing sample members by sampling technique, the results are expected to be representative of the characteristics of the study population (representative). Researchers used processed data using SEM with AMOS version 24 software, which states for optimal data collection is using samples from 100-200 samples and in this study the researchers used census methods, so that the respondents numbering 125 , respondents must fill out a questionnaire that has been distributed.

\subsection{Data Collection Techniques}

For the purposes of the analysis of the problem under study, the data collection is carried out using techniques: 1. Interview, namely question and answer directly to the parties concerned to obtain the desired data and information.

2. Spread the questionnaire that contains questions from each research variable, where the number of questions from each of these variables is 5 questions. Then the questions are weighted based on a Likert scale with a weighting of values 1 to 5 .

3. Document Study, which is studying and observing data or reports contained in the Tanjungpinang City Youth and Sports Service and Tanjungpinang regional library

\subsection{Research Variables}

In this study the variables are divided into independent variables, namely influencing variables, consisting of (X1) Spiritual Motivation, (X2) Leadership, (X3) Communication Style. The other variable is the dependent variable, which is the variable that is affected or which is the result due to the independent variable. In this study there are two dependent variables namely Intervening Variable (Y) Improvement of Organizational Culture, and the dependent variable $(Z)$ Work performance.

\subsection{Data Analysis Techniques}

The analysis used by researchers in this study is path analysis that is by describing a flow chart that can make it easier to see the relationships to be tested. Data analysis was performed using the Structural Equation Modeling (SEM) method and the software used for structural analysis was Amos version 24 of Arbukle and for descriptive using SPSS 24. In this step the suitability of the model was evaluated, through examination of various Goodness of Fit criteria. For this reason, the first step taken is to evaluate whether the data used can meet the SEM assumptions. If these assumptions are met, the model can be tested. According to Ferdinand the assumptions that must be fulfilled in the data collection and processing procedures were analyzed by SEM modeling (Ferdinand 2002) 


\section{Result and Discussion}

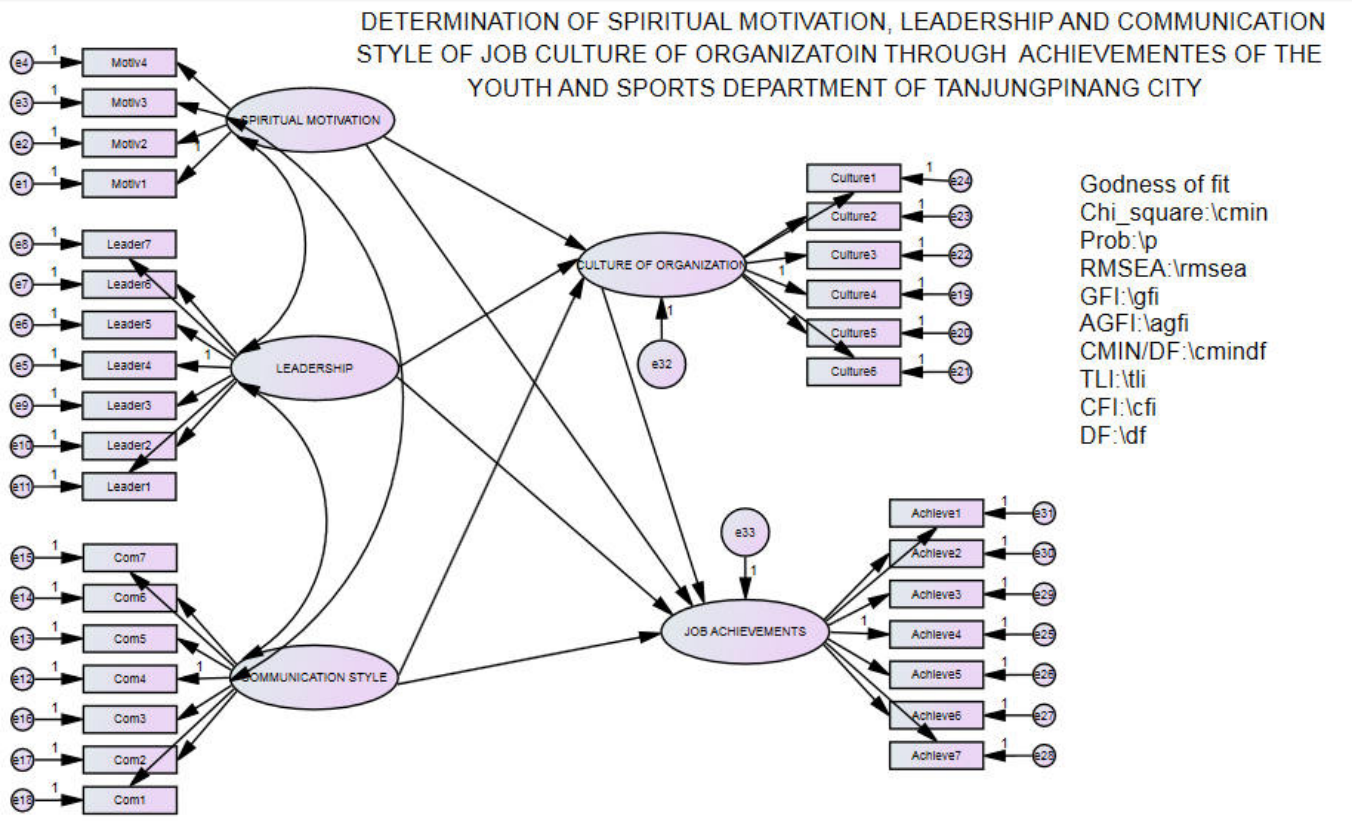

Table 1 Regression Weight (Lamda) Indicator Variable Work Environment, Competence, Self-Efficacy, Job Satisfaction and Organizational Commitment.

\begin{tabular}{|c|c|c|c|c|c|c|c|}
\hline & & & Estimate & S.E. & C.R. & $\mathrm{P}$ & Label \\
\hline CULTURE & $<---$ & MOTIV & ,373 & , 109 & 3,408 & $* * *$ & par_27 \\
\hline CULTURE & $<---$ & LEADER &, 170 &, 096 & 1,759 &, 079 & par_29 \\
\hline CULTURE & $<---$ & COM & ,314 &, 113 & 2,780 &, 005 & par_30 \\
\hline ACHIEVE & $<---$ & MOTIV & ,329 & ,118 & 2,781 & ,005 & par_28 \\
\hline ACHIEVE & $<---$ & LEADER & , 194 & ,097 & 2,012 &, 044 & par_31 \\
\hline ACHIEVE & $<---$ & $\mathrm{COM}$ & ,245 &, 115 & 2,127 &, 033 & par_32 \\
\hline ACHIEVE & $<---$ & CULTURE & ,311 & , 123 & 2,533 & 011 & par_33 \\
\hline
\end{tabular}

Table 2 Standardized Regression Weight (Lamda) Indicator Variables Spiritual Motivation, Leadership, Communication Style, Organizational Culture and Work Achievement.

\begin{tabular}{|ll|r|}
\hline & & Estimate \\
\hline CULTURE $<---$ & MOTIV &, 418 \\
\hline CULTURE $<---$ & LEADER &, 179 \\
\hline CULTURE $<---$ & COM &, 339 \\
\hline ACHIEVE $<---$ & MOTIV &, 315 \\
\hline ACHIEVE $<---$ & LEADER &, 176 \\
\hline ACHIEVE $<---$ & COM &, 227 \\
\hline ACHIEVE $<---$ & CULTURE &, 266 \\
\hline
\end{tabular}

Source: Output IBM SPSS AMOS 24 Report (2020)

Table 3 Squared Multiple Correlations: (Group number 1 - Default model)

\begin{tabular}{|l|r|}
\hline & Estimate \\
\hline CULTURE & $\mathbf{7 8 5}$ \\
\hline ACHIEVE &, 851 \\
\hline
\end{tabular}

Source: Output IBM SPSS AMOS 24 Report (2020)

\section{Analysis Goodness of Fit}

Based on test criteria 2 / df), RMSEA, GFI, AGFI, TLI, and CFI above and the Goodness of Fit value of Amos for windows version 20.0 as shown in the figure above, then the following table can be made. $\chi 2$ ), Relative Chi-square $(\chi$ Based on the test criteria, Chi-square 


\begin{tabular}{|l|l|l|l|}
\hline \multicolumn{2}{l}{ Table 4 Evaluation Goodness of Fit } \\
\begin{tabular}{|l|l|l|l|}
\hline Goodness of Fit Index & Cut-of Value & Model Result & Remarks \\
\hline Chi-square $\left(\square^{2}\right)$ & Less likely & 470,631 & Good \\
\hline Relatitive Chi-square $\left(\square^{2} / \mathrm{df}\right)$ & $\square 3,00$ & $\left.1,110^{*}\right)$ & Good \\
\hline Probability & $>0,05$ & 0,058 & Good \\
\hline RMSEA & $\square 0,08$ & $0,030^{+)}$ & Marginal \\
\hline GFI & $\square 0,90$ & $0,809^{+)}$ & Marginal \\
\hline AGFI & $\square 0,90$ & 0,777 & Poor \\
\hline TLI & $\square 0,94$ & 0,988 & Good \\
\hline CFI & $>0,94$ & 0,989 & Good \\
\hline
\end{tabular}
\end{tabular}

*) Fulfing Goodness of fit

+ ) Marginal

Source: Output IBM SPSS AMOS 24 Report (2020)

2 / df) while the marginal ones were RMSEA, GFI, TLI and CFI. Because only one criterion has been fulfilled and four are marginal out of the eight criteria required, the above model can be stated as a bad model (Solimun 2002) and (Fianto, Hadiwidjojo, and Aisjah n.d.). $\chi$ Taking into account the cut-of-value and goodness of fit results of the model in Table 4.22 above, it appears that Five criteria are met and two are marginal out of the eight criteria used. The criteria fulfilled were Relative Chi-square

1) After theoretical discussion and research, the results of this study can be described as follows: Determination of the latent variable Spiritual Motivation on the latent variable Organizational Culture (Culture) has a standardized estimate (regression weight) of 0.373 with $\mathrm{Cr}$ (Critical ratio = identical with the value of t-count) of 3.408 on probability $=* * *$. CR value $3.408>2,000$ and Probability $=* * *<0.05$ indicates that the determination of the latent variable Spiritual Motivation on the latent variable Organizational Culture (Culture) is significantly positive. This result shows that when the Spiritual Motivation of the employees working in the Tanjungpinang City Youth and Sports Agency improves, the better the Organizational Culture of the employees in the office and vice versa if an employee does not have a good Spiritual Motivation, then the Organizational Culture of the employee will be low. In accordance with what was revealed by (Rosyadi 2010) that Motivation is an Encouragement or energy is a mental and physical movement to act so that motivation is a driving force that moves people to behave in their actions that have certain goals.

2) Determination of latent variables Leadership to the latent variables of Organizational Culture (Culture) has a standardized estimate (regression weight) of 0.170 , with $\mathrm{Cr}$ (Critical ratio $=$ identical to the $\mathrm{t}$-count value) of 1.759 at probability $=0.079$. CR value $-1,759<2,000$ and Probability $=0.079>0.05$ indicate that the Determination of Leadership latent variables to the latent variables of Organizational Culture (Culture) is positively insignificant. These results show that when the leadership owned by employees who work in the Youth and Sports Office of Tanjungpinang City improves, it will not directly make the organizational culture of the employees in the office get better too and vice versa if an employee does not have good leadership, then he will not Significantly determines the organizational culture of these employees will be low. This is according (Hasibuan 2012) a leader is someone with leadership authority directing his subordinates to do part of his work in achieving goals. So that leadership is someone who has the nature to be able to use his authority to be able to direct his subordinates to do some of his work in achieving organizational goals.

3) Determination of latent variables Communication Style (Com) to latent variables Organizational Culture (Culture) has a standardized estimate (regression weight) of 0.314 with $\mathrm{Cr}$ (Critical ratio = identical to the tcount value) of 2.780 at probability $=0.05$. CR value $=2.780>2,000$ and Probability $=0.005<0.05$ indicates that the Determination of the Communication Style (Com) latent variable to the latent variable of Organizational Culture (Culture) is significantly positive. These results show that when the Communication Style of employees working in the Tanjungpinang City Youth and Sports Office improves, the better the Culture of Employee Organization in the office and vice versa if an employee does not have a good Communication Style, then the Culture of Employee Organization will be low. This is in accordance with the theory of Communication Style (Sule and Priansa 2018) states that in general the style is an attitude, movement, behavior, and gestures summarized in the human personality in this case a leader in an organization.

4) Determination of the latent variable Spiritual Motivation (Achiv) of the latent variable Work Achievement (Achieve) has a standardized estimate (regression weight) of 0.329 with $\mathrm{Cr}$ (Critical ratio = identical to the tcount value) of 2.781 at probability $=0.05$. CR2,781 value $>2,000$ and probability $0.005<0.05$ indicate that the determination of the latent variable Spiritual Motivation (Motiv) on the latent variable Job Performance (Achieve) is a significant positive. This result shows that when the Spiritual Motivation of the employees working in the Tanjungpinang City Youth and Sports Service improves, the better the Employee Performance in the office and vice versa if an employee does not have a good Spiritual Motivation, then the Work Performance of the employee will be low. This is in accordance with the theory found if (Hasibuan 2012) 
Motivation is a way to be able to direct the power and potential to want to work productively so that it can reach the set standards and achieve predetermined goals.

5) Determination of latent variables Leadership to latent variables Achievement has a standardized estimate (regressionweight) of 0.194 , with $\mathrm{Cr}$ (Critical ratio $=$ identical to the t-count value) of 2.012 at probability $=$ 0.044. CR value of 2.012 $>2,000$ and Probability $=0.044<0.05$ indicates that the Determination of Leadership latent variables to the Significant Positive Achievement (Achieve) latent variables. These results show that when the leadership of employees who work in the Department of Youth and Sports in Tanjungpinang City improves, the better the Work Achievement of employees in the office and vice versa if an employee does not have a good Leadership, then the employee's Job Performance will be low. In accordance with the theory put forward by (Bangun 2012) states leadership as a psychological process in accepting the responsibilities of the task, self, and the fate of others, from several definitions of leadership, it can be concluded that leadership is an ability to determine enthusiasm, excitement, security, work quality and organizational achievements, as well as the ability to play a role in encouraging individuals and groups to achieve organizational goals.

6) Determination of the latent variable Communication Style (Com) to the latent variable Work Achievement (Achieve) has a standardized estimate (regression weight) of 0.245 with $\mathrm{Cr}$ (Critical ratio $=$ identical to the counts) of 2.127 at probability $=0,033$. CR value $2.127>2,000$ and Probability $=0.033<0.05$ indicates that the Determination of the Communication Style (Com) latent variable to the Job Performance (Achieve) latent variable is significantly positive. These results show that when the Communication Style of employees working in the Department of Youth and Sports in Tanjungpinang City improves, the better the Work Performance of employees in the office and vice versa if an employee does not have a good Communication Style, then the Work Performance of the employee will be low . This is consistent with the theory put forward by (Zainal n.d.) which defines communication as sending and receiving messages or news between two or more people so that the message can be understood.

7) Determination of latent variables Organizational Culture (Culture) to the latent variable Job Performance (Achieve) has a standardized estimate (regression weight) of 0.311 , with $\mathrm{Cr}$ (Critical ratio $=$ identical to the tcount value) of 2.533 at probability $=0.011$. CR value of $2.533>2,000$ and Probability $=0.011<0.05$ indicates that the determination of the latent variable of Organizational Culture (Culture) on the latent variable of Job Performance (Achieve) is positive significant. These results show that when the organizational culture of employees who work in the Youth and Sports Office of Tanjungpinang City improves, the better the Work Performance of employees in the office and vice versa if an employee does not have a good Organizational Culture, the Work Performance of the employee will be low. This is in accordance with the theory put forward by (Rivai and Mulyadi 2012) suggesting Organizational Culture is what employees feel and how this perception creates a model of trust, values, and expectations.

\section{Conclusion}

After theoretical discussion and research, the results of this study can be concluded as follows:

1. The influence of the latent variable Spiritual Motivation on the latent variable Organizational Culture has a standardized estimate (regression weight) of 0.373 with $\mathrm{Cr}$ (Critical ratio = identical to the t-count value) of 3.408 at probability $=* * *$. CR value $3.408>2.00$ and Probability $=* * *<0.05$ indicates that the influence of the latent variable Spiritual Motivation on Variety of Organizational Culture is significantly positive.

2. The influence of Leadership latent variables on Organizational Culture latent variables has a standardized estimate (regression weight) of 0.170 with $\mathrm{Cr}$ (Critical ratio $=$ identical to the t-count value) of 1.759 on probability $=0.079$. CR value $1.759<2.00$ and Probability $=0.079>0.05$ indicates that the influence of the Leadership latent variable on the latent variable of Organizational Culture is positively insignificant.

3. The influence of latent variables Communication Style on latent variables Organizational Culture (Culture) has a standardized estimate (regression weight) of 0.314 with $\mathrm{Cr}$ (Critical ratio = identical to the t-count value) of 2.780 at probability $=0.005$. CR value of $2.780>2.00$ and Probability $=0.005<0.05$ indicates that the influence of the Communication Style variable (Com) on the latent variable of Organizational Culture is significantly positive.

4. The influence of the latent variable Spiritual Motivation on the latent variable Work Achievement has a standardized estimate (regression weight) of 0.329 with a $\mathrm{Cr}$ (Critical ratio = identical to the t-count value) of 2.781 at probability $=0.005$. CR value of $2.781>2.00$ and Probability $=0.005<0.05$ shows that the influence of the Spiritual Motivation latent variable on the Achievement variable is significantly positive.

5. The influence of Leadership latent variables on Achievement has a standardized estimate (regression weight) of 0.194 with $\mathrm{Cr}$ (Critical ratio $=$ identical to the t-count value) of 2.012 on probability $=0.044$. CR value of $2.012>2.00$ and Probability $=0.004<0.05$ indicates that the influence of the Leadership latent variable on the Performance Achievement latent variable is significantly positive.

6. The influence of the latent variable Communication Style on the latent variable Job Performance has a standardized estimate (regression weight) of 0.245 with $\mathrm{Cr}$ (Critical ratio = identical to the t-count value) of 
2.012 on probability $=0.033$. CR value of $2.012>2.00$ and Probability $=0.033<0.05$ indicates that the influence of the Communication Style latent variable on the Job Performance latent variable is significantly positive.

7. The influence of latent variables Organizational Culture on the latent variable Job Performance has a standardized estimate (regression weight) of 0.311 with $\mathrm{Cr}$ (Critical ratio = identical to the t-count value) of 2.533 at probability $=0.011$. CR value of $2.533>2.00$ and Probability $=0.011<0.05$ indicates that the influence of the latent variable of Organizational Culture on the latent variable of Job Performance is significantly positive.

8. Changes in Work Achievement are influenced by Spiritual Motivation, Leadership, Communication Styles and Organizational Culture by $85.21 \%$. While the Change in Organizational Culture is influenced by Spiritual Motivation, Leadership and Communication Style by $78.5 \%$.

\section{References}

Abdullah, Naziruddin, and M. Shabri Abd Majid. 2003. “The Influence of Religiosity, Income and Consumption on Saving Behaviour: The Case of International Islamic University Malaysia (IIUM).” Jurnal Iqtisad 4(1).

Bangun, Wilson. 2012. "Manajemen Sumber Daya Manusia, Jakarta: PT.” Glora Aksara Pratama.

Ferdinand, Augusty. 2002. "Structural Equation Modeling Dalam Penelitian Manajemen." Semarang: Badan Penerbit Universitas Diponegoro.

Fianto, A. Y., Djumilah Hadiwidjojo, and Siti Aisjah. n.d. "Solimun.(2014)." The Influence of Brand Image on Purchase Behaviour through Brand Trust. Business Management and Strategy 5(2):58-76.

Hasibuan, Malayu S. P. 2012. "Manajemen Sumber Daya Manusia Jakarta: Bumi Aksara."

Hasibuan, Malayu S. P. 2013. "Manajemen Sumber Daya Manusia, Cetakan Ke-17, PT.” Bumi Aksara, Jakarta.

Mangkunegara, A. A. Anwar Prabu. 2016. Manajemen Sumber Daya Manusia Perusahaan. PT. Remaja Rosdakarya.

Rivai, Veithzal, and Deddy Mulyadi. 2012. "Kepemimpinan Dan Perilaku Organisasi Edisi Ketiga.” Jakarta: PT. Rajagrafindo Persada.

Robbins, Stephen P., and Timothy A. Judge. 2008. “Perilaku Organisasi Edisi Ke-12.” Jakarta: Salemba Empat 11.

Rosyadi, Slamet. 2010. Paradigma Baru Manajemen Pembangunan. Gava Media.

Ruliana, Poppy. 2014. “Komunikasi Organisasi: Teori Dan Studi Kasus.” Jakarta: PT. Raja Grafindo Persada.

Siswanto, Victorianus Aries. 2012. "Strategi Dan Langkah-Langkah Penelitian.” Yogyakarta: Graha Ilmu.

Solimun, M. S. 2002. "Structural Equation Modelling (SEM) Lisrel Dan Amos." Malang: Fakultas MIPA Universitas Brawijaya.

Sule, Ernie Tisnawati, and Donni Juni Priansa. 2018. "Kepemimpinan Dan Perilaku Organisasi." Bandung: PT Refika Aditama.

Sutrisno, Edy. 2013. "Manajemen Sumber Daya Manusia, Cetakan Kelima.” Yogyakarta: Prenada Media.

Tamami. 2011. "Psikologi Tasawuf." Cetakan Satu. Bandung: Pustaka Setia.

Tampubolon, Manahan P. 2008. "Perilaku Keorganisasian (Organization Behavior) Perspektif Organisasi Bisnis. Edisi Kedua."

Zainal, Veithzal Rivai. n.d. "Dkk.(2014), Manajemen Sumber Daya Manusia Untuk Perusahaan Dari Teori Ke Praktik.” Edisi Ketiga. Jakarta: PT RajaGrafindo Persada Rajawali Pers. 